\title{
Salinomycin intoxication in pigs associated with the use of tiamulin in the State of Santa Catarina, Brazil
}

\section{Intoxicação por salinomicina em suínos associado ao uso de tiamulina no Estado de Santa Catarina}

\author{
Amanda Queiroz de Carvalho ${ }^{1 *}$; Claudia Salete Wisser ${ }^{2}$; Fernanda Laskoski3; \\ Mateus Casalini Maturana3; José Cristani²; Sandra Davi Traverso ${ }^{2}$
}

\section{Highlights}

The association between salinomycin and tiamulin causes myopathy in pigs.

Ionophore omission on the feed label was decisive for intoxication.

Prophylactic measures were important to reduce economic losses.

\begin{abstract}
This paper describes a spontaneous outbreak of toxic myopathy in finishing pigs due to the ingestion of feed with salinomycin associated with tiamulin and addresses the control methods performed during the outbreak to minimize economic losses resulting from the intoxication. A lot of 940 pigs fed feed containing 30 ppm salinomycin received $100 \mathrm{ppm}$ tiamulin (via water) to control recurrent respiratory diseases on the farm. After ingesting tiamulin, some animals manifested clinical signs of motor incoordination, stiff gait, reluctance to move, muscle weakness and tremors, dyspnea, depression, and decubitus, remaining in "sitting-dog position" or with the abduction of the pelvic limbs, and rested on tip-toes when in a standing position. Two animals were euthanized for macro-and microscopic evaluation. The other sick animals received supportive anti-inflammatory treatment. The most relevant macroscopic finding observed during necropsy was the slight pallor of the pelvic limb muscles. The main histopathological findings consisted of multifocal areas of hyaline degeneration and marked necrosis of skeletal myofibers, with macrophage infiltrate associated with cell regeneration and skeletal fiber phagocytosis. These lesions were more intense in the longissimus dorsi, diaphragm, and masseter muscles. The definitive diagnosis was based on epidemiological aspects and clinical lesional conditions compatible with toxic myopathy secondary to ionophore intoxication.
\end{abstract}

Key words: lonophores. Pig farming. Toxic myopathy.

1 Ph.D., Federal Institute of Education, Science and Technology of Paraná, IFPR, Capanema, PR, Brazil. E-mail: amanda. queiroz@ifpr.edu.br

2 Ph.D., State University of Santa Catarina, UDESC, Lages, SC, Brazil. E-mail:claudiawisser@hotmail.com; jose. cristani@udesc.br; sandra.traverso@udesc.br

3 Undergraduate Veterinary Medicine Students, UDESC, Lages, SC, Brazil. E-mail: fernandalaskoski@yahoo.com.br; mateusmaturana@hotmail.com

* Author for correspondence

Received: Oct. 17, 2020 - Approved: Feb. 10, 2020 


\section{Resumo}

Este trabalho descreve um surto espontâneo de miopatia tóxica em suínos na fase de terminação, decorrente da ingestão de ração contendo salinomicina associada a tiamulina e aborda os métodos de controle realizados durante o surto, para minimizar os prejuízos econômicos decorrentes da intoxicação. Um lote de 940 suínos alimentados com ração contendo 30 ppm de salinomicina recebeu tiamulina na dose de 100 ppm (via água) para controle de doenças respiratórias recorrentes na granja. Após a ingestão da tiamulina, alguns animais manifestaram sinais clínicos de incoordenação motora, andar rígido, relutância ao movimento, fraqueza e tremores musculares, dispneia, depressão e decúbito, permanecendo em "posição de cão sentado" ou com abdução dos membros pélvicos, e quando em estação, apoiavam-se nas pinças dos cascos. Dois animais foram eutanasiados para avaliação macro e microscópica. Os demais animais doentes receberam tratamento suporte com anti-inflamatório. O achado macroscópico mais relevante observado durante a necropsia foi palidez leve dos músculos dos membros pélvicos. Os principais achados histopatológicos foram áreas multifocais de degeneração hialina e necrose acentuada de miofibras esqueléticas, com infiltrado de macrófagos associado às figuras de regeneração celular e à fagocitose de fibras esqueléticas. Essas lesões foram mais intensas nos músculos longissimus dorsi, diafragma e masseter. O diagnóstico definitivo baseou-se nos aspectos epidemiológicos e no quadro clínico-lesional compatíveis com miopatia tóxica secundária a intoxicação por ionóforo.

Palavras-chave: Ionóforos. Miopatia tóxica. Suinocultura.

\section{Introduction}

lonophores have been used as coccidiostats in the poultry industry and as performance enhancers in ruminants and pigs (Barragry, 1994). The antibiotic tiamulin has been used in pigs to treat diseases of the respiratory and intestinal tracts (Barcellos \& Sobestiansky, 1998).

These antibiotics do not cause damage to the health of animals when used alone and at adequate doses, but ionophores are myotoxic at excessive doses (Novilla, 1992), when administered to more susceptible species (Salles, Barros, \& Barros, 1994), and associated with drugs that potentiate its effects, as demonstrated by the combination of tiamulin, both orally (drinking water) and intramuscularly, potentiating the monensin effects in pigs (Miller, O'connor, \& Roberts, 1986; Van Vleet, Runnels, Cook, \& Scheidt, 1987).
The minimum and maximum contents of salinomycin as a growth promoter recommended in the diet of pigs up to 4 months of age are 30 and $60 \mathrm{mg} / \mathrm{kg}$, respectively, and up to 6 months old are 15 and 30 ppm, respectively (Nogueira, França, \& Peixoto, 2009). The therapeutic dose of tiamulin is 100 to $200 \mathrm{ppm}$ or 9 to $12 \mathrm{mg} / \mathrm{kg}$ body weight (Barcellos \& Sobestiansky, 1998).

Pigs can be found dead due to ionophore intoxications (Armién, Peixoto, Döbereiner, \& Tokarnia, 1997) and, when still alive, the clinical signs reported are characterized by inappetence, muscle tremors, motor incoordination, ataxia, decubitus (Ganter, Kieckhofer, \& Kucza, 1995; Carpenter, Charbonneau, \& Josephson, 2005), and, occasionally, dark urine (Miskimins \& Neiger, 1996; Plumlee, Johnson, \& Galey, 1995). In Germany, salinomycin intoxication in pigs has been described from $180 \mathrm{mg} / \mathrm{kg}$ of feed (Dost, 
1978 apud Ganter et al., 1995) and at a dose of 8 to $12 \mathrm{mg} / \mathrm{kg} /$ live weight (LW), and when associated with tiamulin at a dose of 2 to $3 \mathrm{mg} /$ $\mathrm{kg} / \mathrm{LW}$ (Wanner, 1984). In Brazil, there is only one report of ionophore (narasin) intoxication in pigs (Armién et al., 1997) and no description of salinomycin intoxication associated with the use of tiamulin in this species. This study aimed to describe the epidemiological, clinical, and pathological aspects observed in an outbreak of salinomycin intoxication associated with tiamulin and report the adopted contro methods during the outbreak as a way to minimize economic losses resulting from the intoxication.

\section{Material and Methods}

Epidemiological data on the disease in pigs occurring on a farm located in the mountainous meso-region of the State of Santa Catarina, Brazil, were obtained from the technician responsible for the property. The farm was visited, and the animals were euthanized for macroscopic and microscopic analysis. Fragments of skeletal muscles (semitendinosus, longissimus dorsi, intercostal, diaphragm, masseter, and serratus), myocardium, central nervous system, and viscera (lung, liver, spleen, and kidney) were collected for histopathological examination. The tissue fragments were fixed in $10 \%$ formaldehyde, processed routinely for histopathology, and stained with hematoxylineosin (HE).

\section{Results and Discussion}

A batch of feed containing $30 \mathrm{ppm}$ of salinomycin (via nucleus) was processed at the feed mill and distributed to 42 finishing pig farms in the partnership system in the mountainous meso-region of the State of Santa Catarina. The feed formula did not mention the presence of salinomycin in the nucleus used for manufacturing.

Pigs in one of the farms that housed 940 finishing pigs in pens of 50 animals showed clinical signs of respiratory diseases such as coughing, sneezing, and abdominal breathing. The tiamulin-based medication was prescribed at a dose of $100 \mathrm{ppm}$ (via water) for a period of eight days to control the respiratory diseases recurrent on the farm.

One animal was found in decubitus on the third day after starting treatment with tiamulin, and another six animals presented motor incoordination, stiff gait, reluctance to move, muscle tremors (mainly in the pelvic limbs), depression, emaciation, anorexia, and decubitus the next day. When in decubitus, the animals presented a "sitting-dog position" with the abduction of the pelvic limbs and rested on tip-toes when in a standing position (Figure 1). 




Figure 1. Spontaneous intoxication by salinomycin and tiamulin in pigs: sick animals in the sittingdog position and with apathy $\left({ }^{*}\right)$ and abduction of the pelvic limbs (arrow).

The most relevant macroscopic lesion in pigs selected for euthanasia and necropsy was the slight pallor of the pelvic limb muscles, with toxic myopathy suspected.

The other sick animals were placed in "hospital pens" and received supportive antiinflammatory treatment. Feed and medication supplied to the lot were immediately replaced due to clinical suspicion. All animals in the lot were sent to the slaughterhouse at the end of the waiting period for salinomycin and tiamulin.
Histological examination of the skeletal musculature revealed extensive multifocal areas of hyaline degeneration and floccular fiber necrosis with macrophage infiltrate (Figure 2) in different degrees of intensity, associated with the formation of myotubes (cell regeneration) and fiber phagocytosis. These injuries were more intense in the longissimus dorsi, diaphragm, and masseter muscles. Myocardium showed multifocal macrophage infiltrate and disappearance of light myofibers. 


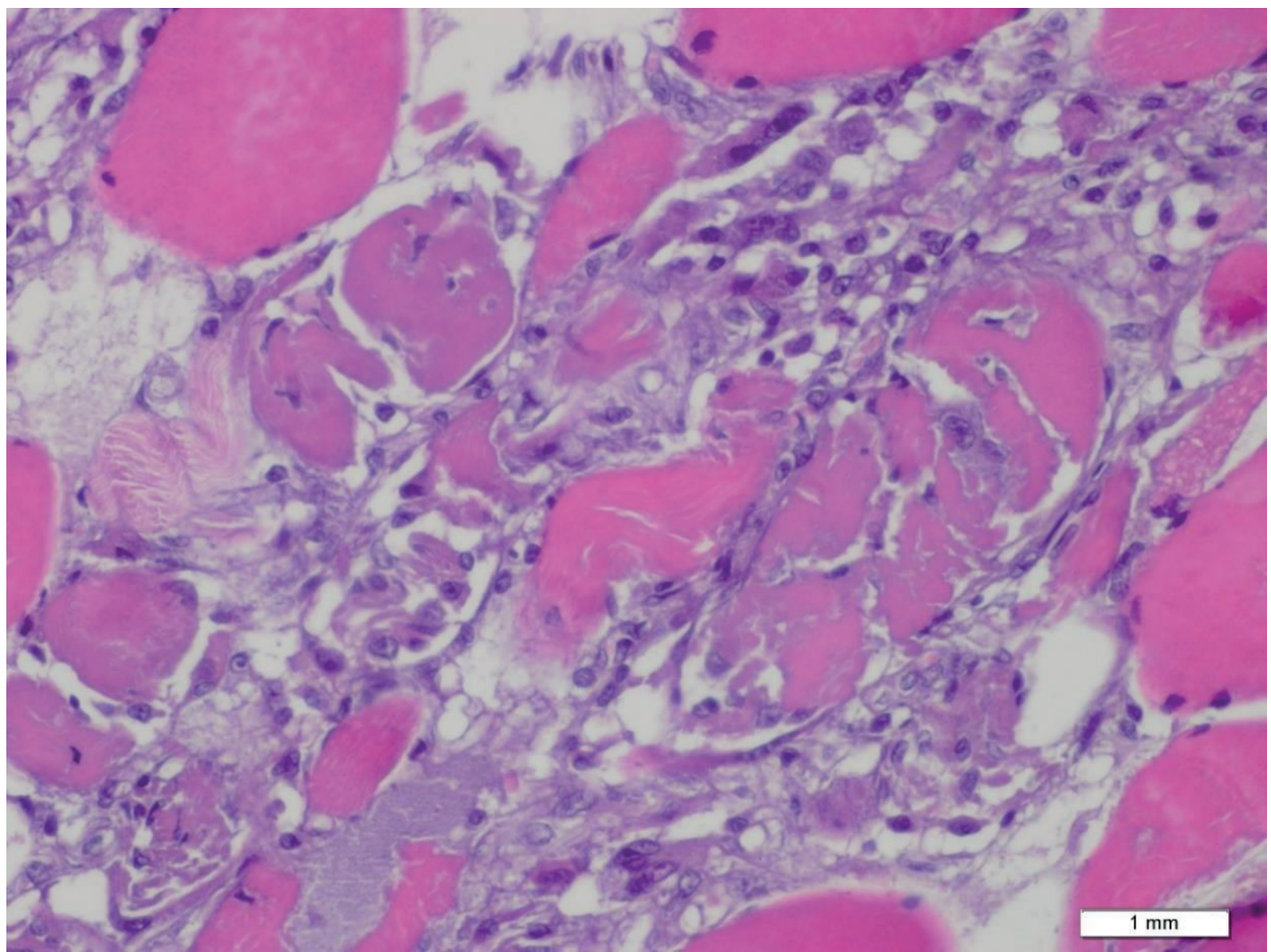

Figure 2. Spontaneous intoxication by salinomycin and tiamulin in pigs: Hyaline degeneration, segmental floccular necrosis of skeletal myofibers associated with an intense macrophage infiltrate. HE, 40x magnification.

The definitive diagnosis of toxic myopathy secondary to ionophore intoxication was made through the association of histological examination and confirmation, by the manufacturer, of the presence of salinomycin in the feed.

Epidemiological data and clinical and lesional signs observed in this report are compatible with toxic myopathy and similar to those described in the literature regarding the ionophore antibiotic intoxication in pigs (Ganter et al., 1995; Plumlee et al., 1995; Carpenter et al., 2005).
The causes of intoxication by ionophores are diverse and may occur due to accidental excessive ingestion (Ribeiro \& Santos, 2016) or error in the mixture of the drug and feed (Ganter, Wendt, \& Kucza, 1989), a mistake in calculating the dose to be offered (Rollinson, Taylor, \& Chesney, 1987; França et al., 2009), use in more susceptible species (Griffiths, Hiller, \& Sutherland, 1989; Salles et al., 1994), and association with drugs that potentiate its action (Drake, 1981; Ganter et al., 1995). 
In the present outbreak, both salinomycin and tiamulin were used within the therapeutic dose for species and animal age (30 ppm and 100 ppm, respectively), indicating that tiamulin interfered with salinomycin excretion, as described by other authors (Ganter et al., 1995; Wendt, Busing, \& Bollwahn, 1997), and that this association was responsible for intoxication. Another factor that corroborates the diagnosis of this pathogenesis is the fact that the animals from the other 41 farms that also received the same batch of feed did not develop toxic myopia because the salinomycin levels were within the allowed for the species.

The difference betweentheobservation of the macroscopic lesion being found only in the musculature of the pelvic limbs and the histological lesion being evident not only in the muscles of the pelvic limbs but in the muscles of the thoracic limbs, loin, and diaphragm can be explained, in this case, by the natural pallor of the swine muscles that made macroscopic visualization of muscle lesions difficult.

Under microscopy, the skeletal striated muscles were more affected than the cardiac muscle, a fact that has been previously reported in other ionophore intoxications in swine (Miskimins \& Neiger, 1996; Armién et al., 1997). This lesional characteristic is important for this animal species, as it facilitates microscopic differentiation of vitamin $\mathrm{E}$ deficiency, which mainly affects the heart muscle and when associated with selenium deficiency, also causes liver and skeletal muscle necrosis (Van Vleet \& Valentine, 2007). For these two diseases, the finding of ionophore antibiotics in the diet and the concomitant cardiac and hepatic lesions are important factors to be considered when formulating the diagnosis.

Variations in the clinical picture observed in this outbreak can be explained by the individual susceptibility to intoxication and the difference between the amount of feed and water ingested by each animal, as it is known that the clinical signs and lesions resulting from the ingestion of toxic levels of ionophores are dependent on the time of exposure to these antibiotics (Rollinson et al., 1987).

The low coefficient of morbidity $(0.7 \%)$ was due to the quality of the farm's technical staff and the early diagnosis of intoxication, which allowed therapeutic and prophylactic measures to be carried out quickly. The prompt replacement of the diet with ionophore by another without the antibiotic and the removal of tiamulin from the water soon after the appearance of the first clinical symptoms, besides the slaughter of all animals after the medication waiting period, was effective in preventing other animals from becoming ill. Another important factor was the presence of hospital pens on the farm, allowing the care and recovery of animals with clinical signs. Although the hospital pens have been recommended since 2006 by Morés and Bordin, the reality in the field has shown that the number of farms that actually have them is still very small.

Pig production $(\mathrm{kg})$ showed a decrease of around $32 \%$ in the lot despite the prompt assistance to the animals and effectiveness of the prophylactic measures taken, as the animals were slaughtered with an average weight of $85 \mathrm{~kg}$, but the company works with an average slaughter weight of $125 \mathrm{~kg}$, which represents approximately $37,520 \mathrm{~kg}$ less production in the slaughter of 938 pigs.

In Brazil, ionophore intoxication in pigs must be distinguished from diseases that present clinical signs of locomotor difficulties, such as intoxications by plants Senna occidentalis, Senna obtusifolia, and Aeschynomene indica, in addition to vitamin $\mathrm{E}$ 
and/or selenium deficiency and porcine stress syndrome.

Porcine stress syndrome produces muscle tremor and stiffness, tachypnea and tachycardia, skin cyanosis, pupillary dilation, and hyperthermia, which can lead to death (Oliveira \& Barcellos, 2007). The disease causes a rapid release of sarcoplasmic calcium from the muscle after bleeding, leading to the manifestation of the PSE (pale, soft, and exudative) flesh (Stalder \& Conaster, 2007). In this case, anamnesis is fundamental for the differentiation of the ionophore intoxication, as the occurrence of PSE is related to stressful factors such as transport, handling, castration, and water and food fasting (Oliveira \& Barcellos, 2007).

Intoxication by $A$. indica seeds produces a clinical picture similar to that of intoxication by ionophores, characterized by varying degrees of uncoordinated walking and falls, sternal decubitus with pelvic limbs in abduction, and inability to get up, but the differential diagnosis is easily made by histology. The clinical picture in ionophore intoxication is due to muscle damage, while the signs of locomotor difficulty due to $A$. indica intoxication are secondary to brain lesions resulting from vascular damage (swelling of endothelial cells, vasogenic edema, and hemorrhage) that evolve to distention of the myelin sheath, causing neuronal death from hypoxia (Oliveira, Rech, Rissi, Barros, \& Barros, 2005).

Intoxication by $S$. occidentalis was reported by Martins, Riet-Correa, Soncini and Paraboni (1986) and, on that occasion, the animals fell ill after the introduction of corn contaminated with $S$. occidentalis seeds into the feed. Macroscopic and microscopic lesions were observed not only in the skeletal muscles but also in the cardiac muscle. Hepatomegaly and hepatocyte vacuolization were observed unlike what happens with ionophore intoxication. Another aspect to be considered is that the pigs presented diarrhea and vomiting in the intoxication by the plant, and both signs were not observed in pigs intoxicated by salinomycin and tiamulin. Despite these differences, intoxication by plants of the genus Senna should not be ruled out as a differential diagnosis.

The association of epidemiology with necropsy and histology examinations in toxic myopia is essential for the formulation of the etiological diagnosis. In this report, there was a lack of knowledge on the part of the technical staff of the integrating company about the presence of salinomycin in the nucleus used to formulate the feed, as the company responsible for producing it did not make this information available on the product label. This factor was decisive for the occurrence of intoxication. The same problem was described by Ganter et al. (1995), who reported a case of toxic myopathy in growing pigs due to the ingestion of salinomycin in the diet associated with the tiamulin prescribed for the treatment of dysentery and pneumonia. Similarly, the information on the feed label did not correspond to its content since it omitted the presence of the ionophore in its composition.

lonophore intoxication is well known in the veterinary world but reports of intoxication in the most different species continue to occur (França et al., 2009; Peixoto, Nogueira, Gonzalez, Tokarnia, \& Franca, 2009; Pavarini et al., 2011; Lucena, Fighera, Tessele, Giaretta, \& Barros, 2012; Ribeiro \& Santos, 2016; Sousa et al., 2019). This study warns of the importance and commitment of manufacturing 
control, labels, and traceability throughout the production chain, as small oversights cause considerable economic losses, in addition to compromising animal welfare.

\section{Conclusion}

Intoxication by salinomycin associated with the use of tiamulin in pigs caused myopathy to vary degrees of intensity, with the longissimus dorsi, diaphragm, and masseter muscles being the most affected. The omission of the presence of ionophore in the feed composition was determinant in the occurrence of intoxication. Prophylactic measures for immediate replacement of medication and feed, treatment of sick animals, and early slaughter of animals after the waiting period were essential for controlling the outbreak and reducing economic losses.

\section{Acknowledgments}

The authors would like to thank the Graduate Program (CAV/UDESC), for granting the PROMOP scholarship, the Federal Institute of Santa Catarina, for the opportunity to participate in the Programa Institucional de Qualificação de Servidores (PIQIFC), and FAPESQ, for supporting the Animal Pathology Research Group.

\section{References}

Armién, A. G., Peixoto, P. V., Döbereiner, J., \& Tokarnia, C. H. (1997). Surto de intoxicação por narasina em suínos. Pesquisa Veterinária Brasileira, 17(2), 63-68. doi: 10.1590/S0100-736X1997000200004
Barcellos, D., \& Sobestiansky, J. (1998). Uso de antimicrobianos em suinocultura. Goiânia: Art. 3 Impressos Especiais.

Barragry, T.B. (1994). Growth Promoting Agents. In Veterinary Drug Therapy (pp.607-615), Lea and Febiger. Philadelphia.

Carpenter, J. A., Charbonneau, G., \& Josephson, G. (2005). Tiamulin and narasin toxicosis in nursey pigs. Journal of Swine Health and Productin, 13(6), 333-336.

Drake, J. N. (1981). Monensin-tiamulin interaction risk to pigs. Veterinary Record, 108, 219-220. doi: 10.1136/vr.108.10.219

França, T. N., Nogueira, V. A., Yamasaki, E. M., Caldas, S. A., Tokarnia, C. H., \& Peixoto, P. V. (2009). Intoxicação acidental por monensina em ovinos no Estado do Rio de Janeiro. Pesquisa Veterinária Brasileira, 29(9), 743-746. doi: 10.1590/S0100736X2009000900011

Ganter, M., Kieckhofer, H. M., \& Kucza, A. (1995). Intoxicação aguda por salinomicina/ tiamulin em suínos. Hora Veterinária, 15(85), 12-16.

Ganter, M., Wendt, M., \& Kucza, A. (1989). Salinomycinvergiftung in einem Schweinemastbestand. Prakt. Tierarzt, 10, 7-12.

Griffiths, G. L., Hiller, P., \& Sutherland, R. J. (1989). Salinomycin poisoning in point-oflay turkeys. Australian Veterinary Journal, 66(10), 326-329. doi: 10.1111/j.17510813.1989.tb09718.x

Lucena, R. B., Fighera, R. A., Tessele, B., Giaretta, P. R., \& Barros, C. S. L. (2012). Surtos de intoxicação por salinomicina em chinchilas (Chinchilla lanígera). Pesquisa Veterinária Brasileira, 32(1), 43-48. doi: 10.1590/S0100-736X2012000100008 
Martins, E., Martins, V. M. V., Riet-Correa, F., Soncini, R. A., \& Paraboni, S. V. (1986). Intoxicação por Cassia Ocidentalis (Leguminoseae) em suínos. Pesquisa Veterinária Brasileira, 6(2), 35-38.

Miller, D. J. S., O'connor, J. J., \& Roberts, N. L. (1986). Tiamulin/salinomycin interactions in pigs. Veterinary Record, 118(3), 73-75. doi: 10.1136/vr.118.3.73

Miskimins, D. W., \& Neiger, R. D. (1996). Monensin toxicosis in swine. Journal of Veterinary Diagnostic Investigation, 8(3), 396-397. doi: $10.1177 / 104063879600800324$

Nogueira, V. A., França, T. N., \& Peixoto, P. V. (2009). Intoxicação por antibióticos ionóforos emanimais. Pesquisa Veterinária Brasileira, 29(3), 191-197. doi: 10.1590/ S0100-736X2009000300001

Novilla, M. N. (1992). The veterinary importance of the toxic syndrome induced by ionophores. Veterinary and Human Toxicology, 34(1), 66-70.

Oliveira, F. N., Rech, R. R., Rissi, D. R., Barros, R. R., \& Barros, C. S. L. (2005). Intoxicação em suínos pela ingestão de sementes de Aeschynomene indica (Leg. Papilionoideae). Pesquisa Veterinária Brasileira, 25(3), 135-142. doi: 10.1590/ S0100-736X2005000300003

Oliveira, S. J., \& Barcellos, D. (2007). Condições diversas. In Sobestiansky \& Barcellos, Doença dos suínos (pp. 664-666). Goiânia, GO: Ed Cânone.

Pavarini, S. P., Wouters, F., Bandarra, P. M. Souza, F. S., Dalto, A. G. C., Gomes, D. C., Driemeier, D. (2011). Surto de intoxicação por monensina em avestruzes e equinos no Sul do Brasil. Pesquisa Veterinária Brasileira, 31(10), 844-850. doi: 10.1590/ S0100-736X2011001000003
Peixoto, P. V., Nogueira, V. A., Gonzalez, A. P., Tokarnia, C. H., \& Franca, T. N. (2009). Accidental and experimental salinomycin poisoning in rabbits. Pesquisa Veterinária Brasileira, 29(9), 695-699. doi: 10.1590/ S0100-736X2009000900002

Plumlee, K. H., Johnson, B., \& Galey, F. D. (1995). Acut salinomycin toxicosis of pigs. Journal of Veterinary Diagnostic Investigation, 7(3), 419-420. doi: 10.1177/ 104063879500700327

Ribeiro, V. M. F., \& Santos, F. G. A. (2016). Alterações clínicas e anatomopatológicas produzidas por intoxicação acidental com salinomicina sódica em catetos (Tayassu tajacu). Revista Brasileira de Medicina Veterinária, 38(1), 69-72. doi: $10.2430 / 00000000000000$

Rollinson, J., Taylor, F. G. R., \& Chesney, J. N. (1987). Salinomycin poisoning in horses. Veterinary Record, 121(6), 126-128. doi: 10.1136/vr.121.6.126

Salles, M. W. S., Barros, C. S. L., \& Barros, S. S. (1994). Ionophore antibiotic (narasin) poisoning in rabbits. Veterinary and Human Toxicology, 36(5), 437-444.

Sousa, D. E. R., Costa, M. M., Ferreira, J. A., Jr., Wilson, T. M., Nascimento, K. A., Pedroso, P. M. O., \& Macedo, J. T. S. A. (2019). Surto de intoxicação por monensina sódica em equinos associada a consumo de suplemento mineral à base de melaço de cana-de-açúcar. Acta Scientiae Veterinariae, 47(Suppl. 1), 363. doi: 10.224 56/1679-9216.89523

Stalder, K., \& Conaster, G. (2007). Porcine stress syndrome and its effects on maternal, feedlot and carcass quantitative and qualitative traits. Tennessee, TN: 
Agricultural Extension Service. Retrieved from http://www.utextension.utk.edu/ publications/pbfiles/PB1606.pdf

Van Vleet, J. F., \& Valentine, B. A. (2007). Muscle and tendon. In M. G. Maxie (Ed.), Jubb, Kennedy \& Palmer's pathology of domestic animals (5nd ed., vol. 2, pp. 185280). San Diego: Academic Press.

Van Vleet, J. F., Runnels, L. J., Cook, J. R., \& Scheidt, A. B. (1987). Monensin toxicosis in swine: potentiation by tiamulin administration and ameliorative effect of treatment with selenium and/or vitamin $\mathrm{E}$. American Journal of Veterinary Research, 48(10), 1520-1524.
Wanner, M. (1984). Unverträglichkeit von Tiamulin und Salinomycin beim Schwein. Schweiz Arch Tierheilkd, 126(10), 521526. doi: 10.5169/seals-591202

Wendt, M., Busing, S., \& Bollwahn, W. (1997). Toxicity of the combination of salinomycin and tiamulin in swine. Dtsch Tierarztl Wochenschr, 104(9), 405-410. 